\title{
ANALISIS BUTIR SOAL TES KENDALI MUTU KELAS XII SMA MATA PELAJARAN EKONOMI AKUNTANSI DI KOTA YOGYAKARTA
}

TAHUN 2012

\section{Oleh :}

\author{
Ata Nayla Amalia ${ }^{1}$ \\ Ani Widayati ${ }^{2}$
}

\begin{abstract}
Abstrak
Penelitian ini bertujuan untuk mengetahui kualitas butir soal Tes Kendali Mutu Kelas XII SMA mata pelajaran Ekonomi Akuntansi di Kota Yogyakarta Tahun 2012 baik soal seri A, B, C, D, maupun E. Soal-soal tersebut dianalisis berdasarkan tingkat validitas, reliabilitas, tingkat kesukaran, daya pembeda, dan efektivitas penggunaan pengecoh/distractor.

Penelitian ini merupakan penelitian deskriptif dengan menggunakan pendekatan kuantitatif karena semua data atau informasi yang diperoleh diwujudkan dalam bentuk angkaangka dan dianalisis dengan statistik menggunakan program Item and Test Analysis (ITEMAN). Subjek dalam penelitian ini adalah siswa kelas XII SMA program studi IPS di Kota Yogyakarta yang diambil berdasarkan kriteria Sekolah Standar Nasional (SSN). Teknik pengumpulan data dilakukan dengan menggunakan metode dokumentasi untuk memperoleh data butir-butir soal, kunci jawaban, dan hasil tes siswa.

Hasil penelitian menunjukkan bahwa: (1) Berdasarkan validitas butir soal yang valid sebesar $87,5 \%$ untuk soal seri A; $95 \%$ untuk soal seri B; $75 \%$ untuk soal seri C; $82,5 \%$ untuk soal seri D; dan $75 \%$ untuk soal seri E. (2) Berdasarkan reliabilitas soal, soal tersebut memiliki koefisien reliabilitas yang tinggi yaitu soal seri A sebesar 0,833; soal seri B sebesar 0,843; soal seri C sebesar 0,803; soal seri D sebesar 0,785; dan soal seri E sebesar 0,768. (3) Berdasarkan tingkat kesukaran, soal dengan tingkat kesukaran sedang adalah $62,5 \%$ untuk soal seri A; $70 \%$ untuk soal seri B; $65 \%$ untuk soal seri C; $52,5 \%$ untuk soal seri D; dan 47,5\% untuk soal seri E. (4) Berdasarkan daya pembeda, soal dengan daya pembeda baik yaitu 55\% untuk soal seri A; $60 \%$ untuk soal seri B; 57,5\% untuk soal seri C; 55\% untuk soal seri D; dan 57,5\% untuk soal seri E. (5) Berdasarkan efektivitas penggunaan distractor, soal dengan distractor yang berkualitas sangat baik sebesar 62,5\% untuk soal seri A; 37,5\% untuk soal seri B; $40 \%$ untuk soal seri C; $50 \%$ untuk soal seri D; dan $35 \%$ untuk soal seri E.
\end{abstract}

\section{A. Pendahuluan}

\section{Latar Belakang}

Perkembangan ilmu pengetahuan dan teknologi telah membawa perubahan yang besar dalam kehidupan manusia serta membawa manusia kepada persaingan global. Tantangan dan perkembangan pendidikan di Indonesia pada saat ini dan masa yang akan datang akan semakin besar dan kompleks. Hal ini disebabkan antara lain adanya perubahan tuntutan

\footnotetext{
${ }^{1}$ Alumni Program Studi Pendidikan Akuntansi UNY

${ }^{2}$ Dosen Jurusan Pendidikan Akuntansi UNY
} 


\section{Jurnal Pendidikan Akuntansi Indonesia, Vol. X, No. 1, Tahun 2012 Ata Nayla Amalia \& Ani Widayati}

Halaman 1 - 26

masyarakat terhadap kualitas dan kuantitas pendidikan itu sendiri. Pendidikan merupakan salah satu sektor penting dalam pembangunan di setiap Negara. Menurut Undang-Undang Nomor 20 Tahun 2003, pendidikan merupakan usaha sadar dan terencana untuk mengembangkan segala potensi yang dimiliki peserta didik melalui proses pembelajaran.

Tiga bagian yang sangat penting dalam pendidikan adalah kurikulum, proses pembelajaran, dan penilaian. Kurikulum merupakan jabaran dari tujuan pendidikan yang menjadi acuan dalam proses pembelajaran. Proses pembelajaran merupakan suatu proses yang ditujukan agar peserta didik dapat belajar melalui perencanaan dan pengaturan lingkungan, sarana, dan prasarana yang mendukung terwujudnya kegiatan belajar. Penilaian merupakan kegiatan yang dilakukan untuk mengukur dan menilai tingkat ketercapaian kurikulum.

Salah satu bentuk penilaian pembelajaran dalam pendidikan adalah ujian nasional. Dalam Peraturan Menteri Pendidikan Nasional No. 20 tahun 2007 mengenai standar penilaian, ujian nasional didefinisikan sebagai kegiatan pengukuran pencapaian kompetensi peserta didik pada beberapa mata pelajaran yang tertera dalam kelompok mata pelajaran ilmu pengetahuan dan teknologi dalam rangka menilai pencapaian Standar Nasional Pendidikan. Pemerintah menyelenggarakan ujian nasional untuk mengetahui pencapaian kompetensi lulusan secara nasional pada mata pelajaran tertentu.

Hasil ujian nasional dapat digunakan untuk berbagai kepentingan antara lain digunakan sebagai salah satu pertimbangan dalam pembinaan dan pemberian bantuan kepada satuan pendidikan dalam upaya meningkatkan mutu pendidikan. Selain itu, hasil ujian nasional digunakan sebagai salah satu penentu kelulusan peserta didik pada seleksi masuk jenjang pendidikan berikutnya. Hasil dari ujian nasional akan dijadikan standar dalam menentukan kelulusan siswa, oleh karena itu tim penyusun soal harus mampu menyusun butir-butir soal agar memiliki tingkat validitas yang tinggi, memiliki daya beda yang baik, serta dapat menentukan opsi pengecoh yang efektif. Hal ini menjadi tugas yang melekat pada seorang penyusun soal ujian nasional untuk membuat soal yang baik dan berkualitas sehingga tidak merugikan peserta didik dalam mencapai kelulusan sekolah.

Sebelum diadakan ujian nasional biasanya Dinas Pendidikan kota atau kabupaten menyelenggarakan tes kendali mutu. Tes kendali mutu ini dilaksanakan dalam rangka meningkatkan mutu kualitas lulusan siswa. Hal ini dilakukan sebagai alat ukur kompetensi siswa dalam pelaksanaan ujian nasional nanti serta sebagai langkah strategis dalam validasi 


\section{Jurnal Pendidikan Akuntansi Indonesia, Vol. X, No. 1, Tahun 2012 Ata Nayla Amalia \& Ani Widayati}

Halaman 1 - 26

data dan mempersiapkan siswa dalam menghadapi ujian nasional. Mengingat pentingnya tes kendali mutu tersebut, maka dalam melaksanakan tes kendali mutu dibutuhkan instrumen butir soal yang berkualitas sehingga dapat menjamin kualitas tes yang disajikan kepada peserta didik. Untuk mendapatkan soal yang bermutu maka sebelum soal digunakan setiap butir soal perlu dianalisis terlebih dahulu. Hal ini bertujuan untuk membantu meningkatkan tes melalui revisi atau membuang soal yang tidak efektif, serta untuk mengetahui informasi apakah peserta didik telah menguasai materi yang diajarkan oleh guru. Analisis butir soal dapat dilakukan secara kualitatif yang berkaitan dengan isi dan bentuk soal maupun kuantitatif yang berkaitan dengan ciri-ciri statistiknya. Menurut Zainal Arifin (2011: 68), instrumen butir soal yang baik memiliki delapan karakteristik yaitu valid, reliabel, relevan, representatif, praktis, diskriminatif, spesifik, dan proporsional.

Setiap tahunnya Dinas Pendidikan Kota Yogyakarta menyelenggarakan tes kendali mutu Sekolah Menengah Atas (SMA) Program Studi Ilmu Pengetahuan Sosial yang meliputi enam mata pelajaran seperti selayaknya mata pelajaran yang diujikan dalam ujian nasional. Salah satu mata pelajaran yang digunakan dalam tes kendali mutu adalah Ekonomi Akuntansi. Soal-soal yang diujikan dalam tes kendali mutu tersebut disusun oleh Musyawarah Guru Mata Pelajaran (MGMP) Ekonomi Akuntansi yang selanjutnya akan digunakan sebagai pengukur dan acuan untuk pembuatan soal ujian nasional.

Berdasarkan informasi yang diperoleh dari Kasubag Perencanaan dan Evaluasi Dinas Pendidikan Kota Yogyakarta, selama ini tim pembuat soal tes kendali mutu belum pernah melakukan analisis butir soal yang telah disusun. Hal ini disebabkan kurang handalnya dan keterbatasan tim pembuat soal untuk melakukan analisis terhadap soal tes kendali mutu. Selama ini tim pembuat soal mengetahui baik atau tidaknya sebuah soal hanya berdasarkan pilihan jawaban terbanyak yang dipilih peserta didik. Adanya hal tersebut membuat tes yang dibuat oleh tim pembuat soal tes kendali mutu belum diketahui kehandalan dan keterpercayaannya, sehingga peserta didik hanya menerima apapun hasilnya. Sering kali kesalahan pengerjaan tes kendali mutu tidak hanya diakibatkan pada kurang telitinya peserta didik dalam mengerjakan akan tetapi diakibatkan oleh lemahnya butir-butir soal pada soal tes kendali mutu yang disusun. Untuk mengetahui butir soal yang berkualitas dan baik sebagai alat ukur hendaklah dilakukan suatu analisis butir soal sehingga dapat diketahui butir soal mana yang harus direvisi atau bahkan mungkin harus dihilangkan sama sekali. 
Di Kota Yogyakarta analisis soal tes kendali mutu baik secara kualitatif maupun kuantitatif belum pernah dilakukan sehingga dari tahun ke tahun kualitas soal tes kendali mutu masih belum diketahui. Analisis terhadap soal tes kendali mutu sangatlah penting dilakukan untuk memperbaiki kualitas soal dan peningkatan mutu soal yang akan diujikan pada tahun-tahun selanjutnya. Soal-soal tes kendali mutu dianalisis untuk diketahui soal yang baik dan soal yang tidak baik. Soal yang baik dapat dijadikan alat ukur dan acuan dalam pembuatan soal ujian nasional. Untuk soal yang tidak baik dapat direvisi sehingga jika digunakan untuk acuan dalam ujian nasional soal tersebut tidak merugikan peserta didik.

Melihat adanya keadaan tersebut maka peneliti tertarik untuk melakukan kajian analisis butir soal tes kendali mutu kelas XII SMA mata pelajaran Ekonomi Akuntansi di Kota Yogyakarta tahun 2012. Penelitian ini digunakan untuk melihat apakah butir-butir soal tes kendali mutu tersebut memiliki kualitas yang baik sehingga mampu mengukur pencapaian kompetensi lulusan peserta didik yang sesungguhnya ataukah belum.

\section{Tujuan Penelitian}

Tujuan penelitian ini adalah untuk mengetahui kualitas butir soal tes kendali mutu kelas XII SMA mata pelajaran Ekonomi Akuntansi di Kota Yogyakarta tahun 2012.

\section{Kajian Pustaka}

\section{a. Pengertian Analisis Butir Soal}

Kegiatan menganalisis butir soal merupakan suatu kegiatan yang harus dilakukan guru untuk meningkatkan mutu soal yang telah ditulis. Tugas melakukan evaluasi terhadap alat pengukuran yang telah digunakan untuk mengukur keberhasilan belajar peserta didik pada umumnya dilupakan oleh evaluator. Menurut Nana Sudjana (2006: 135), “Analisis butir soal atau analisis item adalah pengkajian pertanyaan-pertanyaan tes agar diperoleh perangkat pertanyaan yang memiliki kualitas yang memadai". Menurut Daryanto (2007: 177), “Analisis soal adalah suatu prosedur sistematis, yang akan memberikan informasi-informasi yang sangat khusus terhadap butir tes yang kita susun".

Tujuan penelaahan butir soal adalah untuk mengkaji dan menelaah setiap butir soal agar diperoleh soal yang bermutu untuk digunakan. Di samping itu, tujuan analisis butir soal juga untuk membantu meningkatkan tes melalui revisi atau membuang soal yang tidak efektif 


\section{Jurnal Pendidikan Akuntansi Indonesia, Vol. X, No. 1, Tahun 2012 Ata Nayla Amalia \& Ani Widayati \\ Halaman 1 - 26}

serta untuk mengetahui informasi diagnostik pada peserta didik apakah mereka sudah atau belum memahami materi yang telah diajarkan.

Soal yang bermutu adalah soal yang dapat memberikan informasi setepat-tepatnya sesuai dengan tujuannya, di antaranya dapat menentukan peserta didik mana yang sudah atau belum menguasai materi yang diajarkan guru. Salah satu cara memperbaiki proses belajar-mengajar yang paling efektif adalah dengan cara mengevaluasi tes hasil belajar yang diperoleh dari proses belajar-mengajar itu sendiri. Dengan kata lain, hasil tes tersebut kita olah sedemikian rupa sehingga hasil dari pengolahan itu dapat diketahui komponen manakah dari proses belajar-mengajar itu yang masih lemah. Pengolahan tes hasil belajar dalam rangka memperbaiki proses belajar-mengajar salah satunya adalah dengan melakukan analisis butir soal.

\section{b. Teknik Analisis Butir Soal}

Analisis kualitas tes merupakan suatu tahapan yang harus ditempuh untuk mengetahui derajat kualitas suatu tes. Dalam penilaian hasil belajar diharapkan tes dapat menggambarkan hasil yang objektif dan akurat. Dalam melaksanakan analisis butir soal, pembuat soal dapat melakukan analisis secara kualitatif, dalam kaitannya dengan isi dan bentuk, dan analisis secara kuantitatif dalam kaitannya dengan ciri-ciri statistikanya atau prosedur peningkatan secara judgment dan prosedur peningkatan secara empirik. Analisis kualitatif mencakup pertimbangan validitas isi dan konstruk, sedangkan analisis kuantitatif mencakup pengukuran kesulitan butir soal dan diskriminasi soal yang termasuk validitas dan reliabilitas soal.

1) Validitas

Validitas mencerminkan sejauh mana ketepatan dan kecermatan suatu instrumen tes berfungsi sebagai alat ukur hasil belajar. Suatu tes dapat dikatakan memiliki validitas apabila tes tersebut dapat mengukur objek yang seharusnya diukur dan sesuai dengan kriteria tertentu. Suatu skala atau instrumen pengukur dapat dikatakan mempunyai validitas yang tinggi apabila instrumen tersebut menjalankan fungsi ukurnya, atau memberikan hasil ukur yang sesuai dengan maksud dilakukannya pengukuran tersebut. Tes yang memiliki validitas rendah akan menghasilkan data yang tidak relevan dengan tujuan pengukuran.

a) Validitas Tes

Menurut Anas Sudijono (2011: 163), penganalisisan terhadap tes hasil belajar sebagai suatu totalitas dapat dilakukan dengan dua cara yaitu penganalisisan dengan jalan berpikir 
secara rasional (logical analysis) dan penganalisisan yang dilakukan dengan mendasarkan diri pada kenyataan empiris (empirical analysis).

b) Validitas Item

Menurut Anas Sudijono (2011: 163), validitas item dari suatu tes adalah ketepatan mengukur yang dimiliki oleh sebutir item (yang merupakan bagian tak terpisahkan dari tes sebagai suatu totalitas), dalam mengukur apa yang seharusnya diukur lewat butir item tersebut. Hubungan antara butir item dengan tes hasil belajar sebagai suatu totalitas adalah bahwa semakin banyak butir-butir item yang dapat dijawab oleh peserta didik, maka skor total hasil tes tersebut akan semakin tinggi. Untuk sampai pada kesimpulan bahwa item-item yang ingin diketahui validitasnya, dapat digunakan teknik korelasi sebagai teknik analisisnya. Sebutir item dapat dinyatakan valid apabila skor item yang bersangkutan terbukti memiliki kesejajaran dengan skor total.

2) Reliabilitas

Reliabilitas adalah tingkat atau derajat konsistensi dari suatu instrumen. Reliabilitas tes berkenaan dengan pertanyaan apakah suatu tes teliti dan dapat dipercaya sesuai dengan kriteria yang telah ditetapkan. Suatu tes dikatakan reliabel jika selalu memberikan hasil yang sama bila diteskan pada kelompok yang sama pada waktu atau kesempatan yang berbeda (Zainal Arifin, 2011: 258). Menurut Nana Sudjana (2006: 16), "Reliabilitas alat penilaian adalah ketetapan atau keajegan alat tersebut dalam menilai apa yang dinilainya". Artinya, kapan pun alat penilaian tersebut digunakan akan memberikan hasil yang relatif sama. Hal senada juga diungkapkan Chabib Thoha (2003: 118), "reliabilitas sering diartikan dengan keterandalan”. Artinya, suatu tes memiliki keterandalan jika tes tersebut dipakai mengukur berulang-ulang hasilnya sama. Dengan demikian reliabilitas dapat pula diartikan dengan keajegan atau stabilitas.

Reliabilitas merupakan salah satu persyaratan bagi sebuah tes. Reliabilitas sebuah soal perlu karena sebagai penyokong terbentuknya validitas butir soal sehingga sebuah soal yang valid biasanya reliabel. Untuk mencari reliabilitas tes bentuk objektif dapat dilakukan dengan menggunakan rumus:

$$
r_{11}=\left(\frac{n}{(n-1)}\right)\left(\frac{S^{2}-\sum p q}{S^{2}}\right)
$$

Keterangan ;

$\mathrm{r}_{11}=$ reliabilitas tes secara keseluruhan

$\mathrm{p} \quad=$ proporsi subjek yang menjawab item dengan benar

$\mathrm{q}=$ proporsi subjek yang menjawab item dengan salah $(\mathrm{q}=1-\mathrm{p})$ 
$\sum p q=$ jumlah hasil perkalian antara $\mathrm{p}$ dan $\mathrm{q}$

$n \quad=$ banyaknya item

$\mathrm{S} \quad=$ standar deviasi dari tes

(Suharsimi Arikunto, 2009: 101)

Berbeda dengan soal bentuk objektif, untuk soal bentuk uraian dalam mencari reliabilitas tes dapat dilakukan dengan menggunakan rumus alpha, yaitu:

$$
r_{11}=\left(\frac{n}{(n-1)}\right)\left(1-\frac{\sum \sigma_{i}^{2}}{\sigma_{t}^{2}}\right)
$$

Keterangan ;

$\mathrm{r}_{11}=$ reliabilitas tes secara keseluruhan

$\sum \sigma_{i}^{2}=$ jumlah varians skor tiap item

$\sigma_{t}^{2} \quad=$ varians total

$n \quad$ = banyaknya item

(Suharsimi Arikunto, 2009: 101)

Menurut Nana Sudjana (2006: 17), ada empat cara yang digunakan untuk melakukan uji reliabilitas tes, yaitu:

a) Reliabilitas Tes Ulang

Tes ulang (retest) adalah penggunaan alat penilaian terhadap subjek yang sama dilakukan dua kali dalam waktu berlainan.

b) Reliabilitas Pecahan Setara

Mengukur reliabilitas bentuk pecahan setara tidak dilakukan dengan pengulangan pada subjek yang sama, tetapi menggunakan hasil dari bentuk tes sebanding atau setara dengan yang diberikan kepada subjek yang sama pada waktu yang berbeda. Dengan demikian, diperlukan dua perangkat tes yang disusun agar memiliki derajat kesamaan atau kesetaraan, baik dari segi isi, tingkat kesukaran, abilitas yang diukur, jumlah pertanyaan, bentuk pertanyaan, maupun segi-segi teknis lainnya.

c) Reliabilitas Belah Dua

Dalam prosedur ini tes diberikan kepada kelompok subjek cukup satu kali atau pada satu saat. Butir-butir soal dibagi menjadi dua bagian yang sebanding, biasanya dengan membedakan soal nomor genap dengan soal nomor ganjil. Setiap bagian soal diperiksa hasilnya, kemudian skor dari kedua bagian tersebut dikorelasikan untuk dicari koefisien korelasinya. Mengingat korelasi tersebut hanya berlaku sebagian, tidak untuk seluruh soal, maka koefisien korelasi yang diperolehnya tidak untuk seluruh soal, tetapi hanya untuk separuhnya. 
d) Kesamaan Rasional

Prosedur ini dilakukan dengan menghubungkan setiap butir dalam satu tes dengan butirbutir yang lainnya dalam tes itu sendiri secara keseluruhan.

Dalam penelitian ini untuk mengukur reliabilitas digunakan cara kesamaan rasional. Setiap butir dikorelasikan dengan butir-butir yang lainnya secara keseluruhan

\section{3) Tingkat Kesukaran}

Butir-butir item tes hasil belajar dapat dikatakan sebagai butir item yang baik apabila butir-butir tes tersebut tidak terlalu sukar dan tidak pula terlalu mudah. Dengan kata lain derajat kesukaran tes tersebut adalah sedang atau cukup. Menurut Suharsimi Arikunto (2009: 207) bilangan yang menunjukkan sukar dan mudahnya sesuatu soal disebut indeks kesukaran (difficulty index). Indeks kesukaran butir adalah bilangan yang menunjukkan sukar dan mudahnya soal. Semakin tinggi indeks kesukaran butir maka soal semakin mudah. Soal yang baik adalah soal tidak terlalu mudah atau tidak terlalu sukar. Analisis tingkat kesukaran soal adalah mengkaji soal-soal dari segi kesulitannya sehingga dapat diperoleh soal-soal mana yang termasuk mudah, sedang, dan sukar.

Menurut Witherington dalam Anas Sudijono (2011: 371) dan Arikunto (2009: 207) angka indeks kesukaran butir itu besarnya berkisar antara 0,00 sampai dengan 1,00. Semakin besar angka indeks kesukaran maka soal semakin mudah. Jika seluruh peserta ujian menjawab dengan salah butir tersebut maka soal tersebut sangat sukar dengan angka kesukaran 0,00 dan jika angka kesukaran 1,00 maka soal sangat mudah karena dijawab dengan benar oleh seluruh peserta tes.

Tes terdiri dari dua bentuk yaitu tes objektif dan tes uraian, maka dalam melakukan perhitungan tingkat kesukaran digunakan cara yang berbeda. Untuk tes bentuk objektif dalam menghitung tingkat kesukaran dapat dilakukan dengan menggunakan rumus sebagai berikut:

$$
P=\frac{B}{J S}
$$

\footnotetext{
Keterangan:

$\mathrm{P}=$ angka indeks kesukaran item

$\mathrm{B}$ = banyaknya siswa yang menjawab soal dengan betul

$\mathrm{JS}=$ jumlah seluruh siswa peserta tes
}

(Anas Sudijono, 2011: 370 )

Untuk menghitung tingkat kesukaran tes bentuk uraian menurut Anas Sudijono (2011: 134) langkah-langkah yang dilakukan sebagai berikut:

a) Menghitung rata-rata skor untuk tiap butir soal dengan rumus: 
Rata-rata $=\frac{\text { Jumlah skor peserta didk tiap soal }}{\text { Jumlah peserta didik }}$

b) Menghitung tingkat kesukaran dengan rumus:

Tingkat kesukaran $=\frac{\text { Rata }- \text { rata }}{\text { Skor maksimum tiap soal }}$

c) Membandingkan tingkat kesukaran dengan kriteria tingkat kesukaran.

d) Membuat penafsiran tingkat kesukaran dengan cara membandingkan koefisien tingkat kesukaran dengan kriterianya.

4) Daya Pembeda

Menurut Anas Sudijono (2011: 385), daya pembeda item adalah kemampuan suatu butir item tes hasil belajar untuk dapat membedakan antara testee yang berkemampuan tinggi dengan testee yang berkemampuan rendah. Mengetahui daya pembeda item sangat penting, sebab salah satu dasar pegangan untuk menyusun butir tes hasil belajar adalah adanya anggapan bahwa kemampuan antara testee yang satu dengan testee yang lain berbeda-beda. Selain itu, butir tes hasil belajar harus mampu memberikan hasil tes yang mencerminkan adanya perbedaan kemampuan yang terdapat di kalangan testee tersebut.

Daya pembeda item dapat diketahui dengan melihat besar kecilnya angka indeks diskriminasi item. Angka indeks diskriminasi item adalah sebuah angka atau bilangan yang menunjukkan besar kecilnya daya pembeda (discrimination power) yang dimiliki oleh sebutir item. Sama halnya dengan menganalisis tingkat kesukaran, dalam menganalisis daya pembeda soal bentuk objektif dan bentuk uraian dilakukan dengan cara yang berbeda. Tes bentuk objektif dalam menghitung daya pembeda dapat dilakukan dengan menggunakan rumus sebagai berikut:

$$
\mathrm{D}=P_{A}-P_{B}
$$

Keterangan:

$\mathrm{D}=$ angka indeks diskriminasi

$\mathrm{P}_{\mathrm{A}}=\frac{B_{A}}{J_{A}}=$ proporsi peserta kelompok atas yang menjawab benar

$\mathrm{P}_{\mathrm{B}}=\frac{B_{B}}{J_{B}}=$ proporsi peserta kelompok bawah yang menjawab benar

(Suharsimi Arikunto, 2009: 214)

Untuk soal bentuk uraian, teknik yang digunakan untuk menghitung daya pembeda yaitu:

$$
\mathrm{DP}=\frac{\bar{X} K A-\bar{X} K B}{\text { Skor Maks }}
$$

Keterangan:

DP = daya pembeda

$\bar{X} K A \quad=$ rata-rata dari kelompok atas

$\bar{X} K B \quad=$ rata-rata dari kelompok bawah 
Skor Maks = skor maksimum

(Zainal Arifin, 2011: 133)

\section{5) Fungsi Pengecoh/Distractor}

Berbeda dengan soal bentuk uraian, pada soal pilihan ganda telah dilengkapi beberapa pilihan jawaban. Di antara pilihan jawaban yang ada, hanya satu yang benar. Selain jawaban yang benar tersebut, adalah jawaban yang salah. Jawaban yang salah itulah yang dikenal dengan distractor (pengecoh). Butir soal yang baik, pengecohnya akan dipilih secara merata oleh peserta didik yang menjawab salah. Sebaliknya, butir soal yang kurang baik, pengecohnya akan dipilih secara tidak merata oleh peserta didik.

Tujuan utama dari pemasangan distractor pada setiap butir item adalah agar dari sekian banyak peserta tes yang mengikuti tes hasil belajar ada yang tertarik untuk memilihnya. Distractor akan mengecoh peserta didik yang kurang mampu untuk dapat dibedakan dengan yang mampu. Distractor yang baik adalah yang dapat dihindari oleh peserta didik yang pandai dan akan dipilih oleh peserta didik yang kurang pandai. Dengan demikian distractor baru dapat dikatakan telah berfungsi dengan baik apabila distraktor tersebut telah memiliki daya rangsang atau daya tarik yang baik.

Menurut Anas Sudijono (2011: 411), mengungkapkan bahwa distractor telah dapat menjalankan fungsinya dengan baik apabila distractor tersebut telah dipilih sekurangkurangnya $5 \%$ dari seluruh peserta tes. Distrsctor yang telah menjalankan fungsinya dengan baik dapat digunakan kembali pada tes yang akan datang. Dengan demikian, efektivitas distractor adalah seberapa baik pilihan yang salah tersebut dapat mengecoh peserta tes yang memang tidak mengetahui kunci jawaban yang tersedia. Semakin banyak peserta tes yang memilih distractor tersebut, maka distractor itu dapat menjalankan fungsinya dengan baik. Jika peserta tes mengabaikan semua option (tidak memilih) disebut omit. Dilihat dari segi omit, sebuah item dikatakan baik jika omitnya tidak lebih dari $10 \%$ pengikut tes.

\section{B. Metode Penelitian}

\section{Jenis Penelitian}

Penelitian ini merupakan penelitian analisis dokumen dengan menggunakan pendekatan deskriptif kuantitatif. Menurut Best dalam Sukardi (2011: 157) Penelitian deskriptif merupakan metode penelitian yang berusaha menggambarkan dan menginterprestasi objek sesuai dengan apa adanya. Dalam pelaksanaannya, penelitian ini 
bermaksud untuk mencari informasi dan data yang dapat digunakan untuk mendeskripsikan kualitas soal tes kendali mutu Ekonomi Akuntansi di Kota Yogyakarta. Pendekatan yang digunakan dalam penelitian ini adalah pendekatan kuantitatif karena semua data atau informasi yang diperoleh berupa data numerik yaitu data dalam bentuk angka-angka dan di analisis dengan statistik menggunakan program Item and Test Analysis (ITEMAN).

\section{Tempat dan Waktu Penelitian}

Penelitian ini dilaksanakan di Kota Yogyakarta. Waktu pelaksanaan penelitian bulan Februari-Mei 2012. Data dalam penelitian ini diperoleh pada bulan Maret 2012.

\section{Subjek Penelitian}

Subjek dalam penelitian ini adalah siswa sekolah standar nasional kelas XII Program Studi IPS SMA di Kota Yogyakarta yang berjumlah 715 siswa.

\section{Teknik Pengumpulan Data}

Dalam penelitian ini, teknik pengumpulan data yang digunakan adalah metode dokumentasi. Metode dokumentasi adalah pengumpulan data dengan cara mengutip data atau keterangan yang ada di Dinas Pendidikan atau dengan mempelajari data-data yang tertulis atau tercatat yang ada hubungannya dengan masalah yang diteliti. Metode dokumentasi digunakan untuk mendapatkan data butir -butir soal, kunci jawaban, dan jawaban tes kendali mutu mata pelajaran Ekonomi Akuntansi tahun 2012.

\section{Teknik Analisis Data}

a. Validitas Butir Soal

Uji validitas item dengan menggunakan rumus $\gamma_{\mathrm{pbi}}$ sebagai berikut:

$$
\gamma_{\mathrm{pbi}}=\frac{M p-M t}{S t} \sqrt{\frac{p}{q}}
$$

Keterangan :

$\gamma_{\mathrm{pbi}}=$ koefisien korelasi biserial

$\mathrm{M}_{\mathrm{p}}=$ rerata skor subjek yang menjawab betul bagi item yang dicari validitasnya.

$\mathrm{M}_{\mathrm{t}}=$ rerata skor total

$\mathrm{S}_{\mathrm{t}}=$ standar deviasi dari skor total 
$\mathrm{P}=$ proporsi siswa yang menjawab benar

Q =proporsi siswa yang menjawab salah

(Suharsimi Arikunto, 2009: 79) $\gamma_{\text {pbi }}$ yang diperoleh dari perhitungan rumus di atas selanjutnya dikonsultasikan dengan $r$ tabel pada taraf signifikansi 5\%, apabila $\gamma_{p b i}>r_{t}$ maka butir soal tersebut valid.

\section{b. Reliabilitas}

Untuk menguji reliabilitas soal digunakan rumus Kuder-Richardson (KR-20) sebagai berikut:

$$
r_{11}=\left(\frac{n}{(n-1)}\right)\left(\frac{S^{2}-\sum p q}{S^{2}}\right)
$$

Keterangan ;

$\mathrm{r}_{11}=$ reliabilitas tes secara keseluruhan

$\mathrm{p} \quad=$ proporsi subjek yang menjawab item dengan benar

$\mathrm{q} \quad=$ proporsi subjek yang menjawab item dengan salah $(\mathrm{q}=1-\mathrm{p})$

$\sum p q=$ jumlah hasil perkalian antara $\mathrm{p}$ dan $\mathrm{q}$

$n \quad=$ banyaknya item

$\mathrm{S} \quad=$ standar deviasi dari tes

(Suharsimi Arikunto, 2009: 101)

Selanjutnya hasil perhitungan akan diinterpretasikan terhadap koefisien atau nilai $r$ sebagai berikut:

1) Apabila $r_{11}$ sama dengan atau lebih besar dari 0,70 , maka hasil tes yang sedang diuji reliabilitasnya telah memiliki reliabilitas yang tinggi.

2) Apabila $r_{11}$ lebih kecil dari 0,70 , maka hasil tes yang sedang diuji reliabilitasnya dinyatakan belum memiliki reliabilitas yang tinggi.

(Anas Sudijono, 2011: 209)

\section{c. Tingkat Kesukaran}

Tingkat kesulitas item tes dapat diketahui dari besar kecilnya angka indeks kesukaran yang dapat diperoleh dengan menggunakan rumus yang dikemukakan oleh $\mathrm{Du}$ Bois, yaitu:

$$
P=\frac{B}{J S}
$$

Keterangan:

$\mathrm{P}=$ angka indeks kesukaran item

$\mathrm{B}$ = banyaknya siswa yang menjawab soal dengan betul

$\mathrm{JS}=$ jumlah seluruh siswa peserta tes

(Anas Sudijono, 2011: 370 )

Untuk mengintepretasikan terhadap angka indeks kesukaran butir soal digunakan klasifikasi yaitu:

1) Soal dengan $P 0,000$ sampai 0,299 adalah soal yang sukar 
2) Soal dengan $P$ 0,300 sampai 0,699 adalah soal yang sedang

3) Soal dengan $P$ 0,700 sampai 1,000 adalah soal yang mudah

(Suharsimi Arikunto, 2009: 210)

Soal yang dianggap baik adalah soal yang termasuk kategori sedang, yaitu soal yang memiliki indeks kesukaran 0,300 sampai 0,699.

\section{d. Daya Pembeda}

Rumus untuk menentukan indeks diskriminasi adalah:

$$
\mathrm{D}=\frac{B_{A}}{J_{A}}-\frac{B_{B}}{J_{B}}=P_{A}-P_{B}
$$

Keterangan:

$\mathrm{D}=$ angka indeks diskriminasi

$\mathrm{J}=$ jumlah peserta tes

$\mathrm{J}_{\mathrm{a}}=$ banyaknya peserta tes kelompok atas

$\mathrm{J}_{\mathrm{B}}=$ banyaknya peserta tes kelompok bawah

$\mathrm{B}_{\mathrm{a}}=$ banyaknya peserta kelompok atas yang menjawab soal dengan benar

$\mathrm{B}_{\mathrm{B}}=$ banyaknya peserta kelompok bawah yang menjawab soal dengan benar

$\mathrm{P}_{\mathrm{A}}=\frac{B_{A}}{J_{A}}=$ proporsi peserta kelompok atas yang menjawab benar

$\mathrm{P}_{\mathrm{B}}=\frac{B_{B}}{J_{B}}=$ proporsi peserta kelompok bawah yang menjawab benar

Untuk mengintepretasikan terhadap angka indeks diskriminasi butir soal digunakan klasifikasi yaitu:

a. D : $0,00-0,19$ : jelek (poor)

b. D : $0,20-0,39$ : cukup (satisfactory)

c. D : $0,40-0,69$ : baik (good)

d. D : $0,70-1,00$ : baik sekali (excellent)

e. D : negatif, semuanya tidak baik, jadi semua butir soal yang mempunyai nilai D negatif sebaiknya dibuang.

Butir-butir soal yang baik adalah butir-butir soal yang mempunyai indeks diskriminasi 0,40 sampai 0,69 .

\section{e. Efektivitas Pengecoh/Distractor}

Sebuah pengecoh atau distractor dapat dikatakan berfungsi dengan baik apabila distractor tersebut mempunyai daya tarik yang besar bagi peserta tes yang kurang memahami konsep atau kurang menguasai bahan. Suatu distractor dapat dikatakan berfungsi dengan baik jika paling sedikit dipilih oleh $5 \%$ pengikut tes.

\section{Hasil Penelitian dan Pembahasan}




\section{Hasil Analisis Data}

a. Validitas

Pengujian validitas tes dapat dilakukan dengan dua cara yaitu secara rasional (validitas rasional) dan empiris (validitas empiris). Untuk menentukan validitas rasional dilakukan penelusuran melalui segi isi (validitas isi). Untuk pengujian validitas isi digunakan soal seri A sebagai contoh pengujiannya. Adapun persebaran butir soal seri A berdasarkan indeks validitas isi adalah sebagai berikut:

Tabel 1. Distribusi soal Tes Kendali Mutu kelas XII SMA mata pelajaran Ekonomi Akuntansi di Kota Yogyakarta tahun 2012 seri A berdasarkan indeks validitas isi.

\begin{tabular}{|c|c|c|c|c|}
\hline NO. & KOMPETENSI & INDIKATOR & $\begin{array}{l}\text { NO. } \\
\text { SOAL }\end{array}$ & $\begin{array}{l}\text { JUMLAH } \\
\text { SOAL }\end{array}$ \\
\hline \multirow[t]{6}{*}{1.} & \multirow{6}{*}{$\begin{array}{l}\text { Memahami } \\
\text { permasalahan } \\
\text { ekonomi dalam } \\
\text { kaitannya dengan } \\
\text { kebutuhan manusia, } \\
\text { kelangkaan dan } \\
\text { sistem ekonomi, } \\
\text { konsep ekonomi } \\
\text { dalam kaitannya } \\
\text { dengan kegiatan } \\
\text { ekonomi } \\
\text { konsumen dan } \\
\text { produsen, } \\
\text { permintaan, } \\
\text { penawaran, harga } \\
\text { keseimbangan, dan } \\
\text { pasar. }\end{array}$} & $\begin{array}{l}\text { Mendeskripsikan kebutuhan manusia, } \\
\text { kelangkaan, masalah pokok ekonomi. }\end{array}$ & 1,2 & 2 \\
\hline & & $\begin{array}{l}\text { Mendeskripsikan biaya peluang } \\
\text { (hilangnya kesempatan pada tenaga } \\
\text { kerja), sistem ekonomi. }\end{array}$ & 3 & 1 \\
\hline & & $\begin{array}{l}\text { Mendeskripsikan pola perilaku } \\
\text { konsumen dalam mencapai kepuasan } \\
\text { maksimal dan pola perilaku produsen } \\
\text { dalam mencapai laba/output maksimal, } \\
\text { peran konsumen dan produsen }\end{array}$ & 4 & 1 \\
\hline & & $\begin{array}{l}\text { Mendeskripsikan pelaku ekonomi atau } \\
\text { interaksinya } \\
\text { dalam suatu perekonomian. }\end{array}$ & & \\
\hline & & $\begin{array}{l}\text { Mendeskripsikan permintaan dan } \\
\text { penawaran, harga dan jumlah } \\
\text { keseimbangan dengan tabel, grafik, atau } \\
\text { perhitungan matematika. }\end{array}$ & $\begin{array}{l}5,7,8 \\
13\end{array}$ & 4 \\
\hline & & $\begin{array}{l}\text { Mendeskripsikan pasar barang atau } \\
\text { pasar faktor produksi. }\end{array}$ & 6,9 & 2 \\
\hline \multirow[t]{4}{*}{2.} & \multirow{4}{*}{$\begin{array}{l}\text { Memahami } \\
\text { kebijakan } \\
\text { pemerintah dalam } \\
\text { bidang ekonomi, } \\
\text { Produk Domestik } \\
\text { Bruto (PDB), } \\
\text { Produk Domestik } \\
\text { Regional Bruto } \\
\text { (PDRB), } \\
\text { Pendapatan } \\
\text { Nasional (PN), } \\
\text { inflasi, konsumsi, } \\
\text { investasi, uang dan }\end{array}$} & $\begin{array}{l}\text { Mendeskripsikan ekonomi mikro dan } \\
\text { ekonomi makro } \\
\text { atau masalah yang dihadapi pemerintah } \\
\text { di bidang ekonomi. }\end{array}$ & & \\
\hline & & $\begin{array}{l}\text { Mendeskripsikan konsep PDB, PDB } \\
\text { harga berlaku, PDB harga konstan, } \\
\text { pendapatan nasional, } \\
\text { pendapatan perkapita }\end{array}$ & 11,12 & 2 \\
\hline & & $\begin{array}{l}\text { Mendeskripsikan indeks harga, inflasi } \\
\text { berdasarkan data atau grafik }\end{array}$ & & \\
\hline & & $\begin{array}{l}\text { Mendeskripsikan fungsi konsumsi dan } \\
\text { fungsi tabungan atau investasi } \\
\text { berdasarkan data, atau grafik }\end{array}$ & 14 & 1 \\
\hline
\end{tabular}




\begin{tabular}{|c|c|c|c|c|}
\hline & perbankan. & $\begin{array}{l}\text { Mendeskripsikan konsep dan teori uang, } \\
\text { perbankan, atau kebijakan pemerintah } \\
\text { di bidang moneter. }\end{array}$ & 15 & 1 \\
\hline \multirow[t]{4}{*}{3.} & \multirow{4}{*}{$\begin{array}{l}\text { Memahami kondisi } \\
\text { ketenagakerjaan dan } \\
\text { dampaknya } \\
\text { terhadap } \\
\text { pembangunan } \\
\text { ekonomi, APBN } \\
\text { dan APBD, } \\
\text { perekonomian } \\
\text { terbuka, serta } \\
\text { mengenal pasar } \\
\text { modal }\end{array}$} & $\begin{array}{l}\text { Mendeskripsikan ketenagakerjaan, } \\
\text { pembangunan } \\
\text { ekonomi dan pertumbuhan ekonomi, } \\
\text { pengangguran atau dampaknya } \\
\text { berdasarkan data atau grafik }\end{array}$ & 16,17 & 2 \\
\hline & & $\begin{array}{l}\text { Mendeskripsikan APBN dan APBD, } \\
\text { kebijakan pemerintah di bidang fiskal, } \\
\text { sumber-sumber } \\
\text { penerimaan atau pengeluaran } \\
\text { pemerintah }\end{array}$ & $\begin{array}{l}10,18 \\
19,\end{array}$ & 3 \\
\hline & & $\begin{array}{l}\text { Mendeskripsikan bursa efek, } \\
\text { mekanisme kerja bursa efek }\end{array}$ & 20 & 1 \\
\hline & & $\begin{array}{l}\text { Mendeskripsikan perdagangan } \\
\text { internasional valuta asing, neraca } \\
\text { pembayaran atau devisa }\end{array}$ & 21,22 & 2 \\
\hline \multirow[t]{4}{*}{4.} & \multirow[t]{4}{*}{$\begin{array}{l}\text { Memahami } \\
\text { penyusunan siklus } \\
\text { akuntansi } \\
\text { perusahaan jasa }\end{array}$} & $\begin{array}{l}\text { Mendeskripsikan akuntansi sebagai } \\
\text { sistem informasi, persamaan akuntansi, } \\
\text { mencatat mekanisme debit } \\
\text { dan kredit }\end{array}$ & 23 & 1 \\
\hline & & $\begin{array}{l}\text { Mencatat transaksi ke dalam jurnal } \\
\text { umum atau buku besar berdasarkan } \\
\text { transaksi/dokumen }\end{array}$ & 24,25 & 2 \\
\hline & & $\begin{array}{l}\text { Membuat jurnal penyesuaian dan kertas } \\
\text { kerja perusahaan jasa }\end{array}$ & 26 & 1 \\
\hline & & $\begin{array}{l}\text { Membuat laporan keuangan perusahaan } \\
\text { jasa }\end{array}$ & 27 & 1 \\
\hline \multirow[t]{5}{*}{5.} & \multirow{5}{*}{$\begin{array}{l}\text { Memahami } \\
\text { penyusunan siklus } \\
\text { akuntansi } \\
\text { perusahaan dagang } \\
\text { dan penutupan } \\
\text { siklus akuntansi } \\
\text { perusahaan dagang }\end{array}$} & $\begin{array}{l}\text { Mencatat jurnal khusus, buku besar } \\
\text { utama, buku besar pembantu } \\
\text { perusahaan dagang }\end{array}$ & 28,29 & 2 \\
\hline & & $\begin{array}{l}\text { Menghitung harga pokok penjualan } \\
\text { berdasarkan data }\end{array}$ & 30 & 1 \\
\hline & & $\begin{array}{l}\text { Membuat jurnal penyesuaian dan atau } \\
\text { kertas kerja perusahaan dagang }\end{array}$ & 31,32 & 2 \\
\hline & & $\begin{array}{l}\text { Mendeskripsikan laporan keuangan } \\
\text { serta perhitungannya }\end{array}$ & 33 & 1 \\
\hline & & $\begin{array}{l}\text { Mencatat jurnal penutup, posting ke } \\
\text { jurnal penutup } \\
\text { ke buku besar atau neraca saldo setelah } \\
\text { penutupan. }\end{array}$ & 34,35 & 2 \\
\hline \multirow[t]{2}{*}{6.} & \multirow{2}{*}{$\begin{array}{l}\text { Memahami } \\
\text { manajemen, badan } \\
\text { usaha dalam } \\
\text { perekonomian } \\
\text { nasional, } \\
\text { pengelolaan }\end{array}$} & $\begin{array}{l}\text { Mendeskripsikan manajemen dan badan } \\
\text { usaha }\end{array}$ & 36,37 & 2 \\
\hline & & $\begin{array}{l}\text { Mendeskripsikan cara pengembangan } \\
\text { koperasi, koperasi sekolah atau } \\
\text { menghitung pembagian sisa } \\
\text { hasil usaha berdasarkan data }\end{array}$ & 38,39 & 2 \\
\hline
\end{tabular}


Jurnal Pendidikan Akuntansi Indonesia, Vol. X, No. 1, Tahun 2012

Ata Nayla Amalia \& Ani Widayati

Halaman 1 - 26

\begin{tabular}{|l|l|l|l|c|}
\hline & $\begin{array}{l}\text { koperasi, dan } \\
\text { kewirausahaan }\end{array}$ & Mendeskripsikan kewirausahaan & 40 & 1 \\
\hline
\end{tabular}

Untuk pengujian validitas secara empiris, validitas butir soal dapat diketahui dengan menggunakan rumus korelasi point biserial $\left(r_{p b i}\right)$. Jumlah siswa yang digunakan sebagai subjek penelitian di Kota Yogyakarta adalah 715 siswa dengan rincian 139 siswa mengerjakan soal seri A, 145 siswa mengerjakan soal seri B, 150 siswa mengerjakan soal seri C, 145 siswa mengerjakan soal seri D, dan 136 siswa mengerjakan soal seri E.

Dengan demikian nilai $r$ tabel untuk masing-masing soal yaitu $r_{t}=0,165$ untuk soal seri $\mathrm{A} ; r_{t}=0,162$ untuk soal seri $\mathrm{B} ; r_{t}=0,159$ untuk soal seri $\mathrm{C} ; r_{t}=0,162$ untuk soal seri D; dan $r_{t}=0,167$ untuk soal seri E. Hasil analisis terhadap validitas item soal Tes Kendali Mutu kelas XII SMA mata pelajaran Ekonomi Akuntansi di Kota Yogyakarta tahun 2012 berdasarkan patokan bahwa $r_{p b i} \geq r_{t}$ berarti valid, sedangkan apabila $r_{p b i}<r_{t}$ maka soal tidak valid.

Adapun distribusi butir soal Tes Kendali Mutu kelas XII SMA mata pelajaran Ekonomi Akuntansi di Kota Yogyakarta tahun 2012 berdasarkan indeks validitasnya adalah sebagai berikut:

Tabel 2. Distribusi soal berdasarkan indeks validitasnya.

\begin{tabular}{|l|l|l|}
\hline SOAL TKM & VALID & TIDAK VALID \\
\hline SOAL SERI A & $87,5 \%$ & $12,5 \%$ \\
\hline SOAL SERI B & $95 \%$ & $5 \%$ \\
\hline SOAL SERI C & $75 \%$ & $25 \%$ \\
\hline SOAL SERI D & $82,5 \%$ & $17,5 \%$ \\
\hline SOAL SERI E & $75 \%$ & $25 \%$ \\
\hline
\end{tabular}

\section{b. Reliabilitas}

Reliabilitas soal dihitung dengan menggunakan rumus KR-20. Hasil analisis soal Tes Kendali Mutu kelas XII SMA mata pelajaran Ekonomi Akuntansi di Kota Yogyakarta tahun 2012 berdasarkan patokan bahwa apabila $r_{11} \geq 0,70$ maka soal yang diujikan memiliki reliabilitas yang tinggi, tetapi apabila $r_{11}<0,70$ maka soal yang diujikan memiliki reliabilitas yang rendah atau tidak reliabel.

Adapun besarnya tingkat reliabilitas masing-masing soal Tes Kendali Mutu kelas XII SMA mata pelajaran Ekonomi Akuntansi di Kota Yogyakarta tahun 2012 adalah sebagai berikut: 
Jurnal Pendidikan Akuntansi Indonesia, Vol. X, No. 1, Tahun 2012

Ata Nayla Amalia \& Ani Widayati

Halaman 1 - 26

Tabel 3. Tingkat reliabilitas soal

\begin{tabular}{|l|l|c|}
\hline No. & \multicolumn{1}{|c|}{ Soal } & Tingkat Reliabilitas \\
\hline a. & Soal Tes Kendali Mutu Seri A & 0,833 \\
\hline b. & Soal Tes Kendali Mutu Seri B & 0,843 \\
\hline c. & Soal Tes Kendali Mutu Seri C & 0,803 \\
\hline d. & Soal Tes Kendali Mutu Seri D & 0,785 \\
\hline e. & Soal Tes Kendali Mutu Seri E & 0,768 \\
\hline
\end{tabular}

Dari hasil analisis menunjukkan bahwa soal Tes Kendali Mutu kelas XII SMA mata pelajaran Ekonomi Akuntansi di Kota Yogyakarta tahun 2012 memiliki indeks reliabilitas sebesar 0,833 untuk soal seri A; 0,843 untuk soal seri B; 0,803 untuk soal seri C; 0,785 untuk soal seri D; dan 0,768 untuk soal seri E.

\section{c. Tingkat Kesukaran}

Tingkat kesukaran butir soal dapat diketahui melalui proportional correct yang dihitung dengan program iteman. Klasifikasi yang digunakan untuk mengintepretasikan hasil perhitungan tingkat kesukaran butir soal yaitu 0,000-0,299 termasuk soal kategori sukar; 0,300-0,699 termasuk soal kategori sedang: dan 0,700-1,000 termasuk soal kategori mudah.

Adapun distribusi butir soal berdasarkan tingkat kesukaran soal Tes Kendali Mutu kelas XII SMA mata pelajaran Ekonomi Akuntansi di Kota Yogyakarta tahun 2012 adalah sebagai berikut:

Tabel 4. Distribusi soal berdasarkan tingkat kesukaran.

\begin{tabular}{|l|l|l|l|}
\hline \multirow{2}{*}{ SOAL TKM } & \multicolumn{3}{|c|}{ KATEGORI } \\
\cline { 2 - 4 } & SUKAR & SEDANG & MUDAH \\
\hline SOAL SERI A & $32,5 \%$ & $62,5 \%$ & $5 \%$ \\
\hline SOAL SERI B & $25 \%$ & $70 \%$ & $5 \%$ \\
\hline SOAL SERI C & $27,5 \%$ & $65 \%$ & $7,5 \%$ \\
\hline SOAL SERI D & $40 \%$ & $52,5 \%$ & $7,5 \%$ \\
\hline SOAL SERI E & $37,5 \%$ & $47,5 \%$ & $15 \%$ \\
\hline
\end{tabular}

\section{d. Daya Pembeda}

Daya pembeda butir soal dapat diketahui dengan melihat besar kecilnya indeks diskriminasi. Klasifikasi yang digunakan untuk mengintepretasikan hasil perhitungan daya pembeda yaitu: 0,00-0,19 termasuk dalam kategori jelek (poor); 0,20-0,39 termasuk dalam kategori cukup (satisfactory); 0,40-0,69 termasuk dalam kategori baik (good); dan 0,70-1,00 termasuk dalam kategori baik sekali (excellent). 
Adapun distribusi butir soal Tes Kendali Mutu kelas XII SMA mata pelajaran Ekonomi Akuntansi di Kota Yogyakarta tahun 2012 berdasarkan daya pembeda adalah sebagai berikut:

Tabel 5. Distribusi soal berdasarkan daya pembeda.

\begin{tabular}{|l|l|l|l|l|l|}
\hline \multirow{2}{*}{ SOAL TKM } & \multicolumn{5}{|c|}{ KATEGORI } \\
\cline { 2 - 6 } & JELEK & CUKUP & BAIK & BAIK SEKALI & NEGATIF \\
\hline SOAL SERI A & $7,5 \%$ & $17,5 \%$ & $55 \%$ & $15 \%$ & $5 \%$ \\
\hline SOAL SERI B & $2,5 \%$ & $22,5 \%$ & $60 \%$ & $12,5 \%$ & $2,5 \%$ \\
\hline SOAL SERI C & $15 \%$ & $7,5 \%$ & $57,5 \%$ & $10 \%$ & $10 \%$ \\
\hline SOAL SERI D & $10 \%$ & $22,5 \%$ & $55 \%$ & $5 \%$ & $7,5 \%$ \\
\hline SOAL SERI E & $12,5 \%$ & $17,5 \%$ & $57,5 \%$ & $5 \%$ & $7,5 \%$ \\
\hline
\end{tabular}

\section{e. Efektivitas Penggunaan Pengecoh/Distractor}

Efektivitas penggunaan pengecoh/distractor dapat diketahui melalui nilai proportional endorsing. Suatu butir soal dapat dikategorikan sebagai soal yang baik apabila distractor atau pengecohnya dapat berfungsi dengan baik. Distractor yang berfungsi dengan baik ditandai dengan dipilih oleh sedikitnya $5 \%$ dari peserta tes.

Adapun distribusi butir soal Tes Kendali Mutu kelas XII SMA mata pelajaran Ekonomi Akuntansi di Kota Yogyakarta tahun 2012 berdasarkan efektivitas pengecoh adalah sebagai berikut:

Tabel 6. Distribusi soal berdasarkan efektivitas pengecoh.

\begin{tabular}{|l|l|l|l|l|l|}
\hline \multirow{2}{*}{ SOAL TKM } & \multicolumn{5}{|c|}{ KATEGORI } \\
\cline { 2 - 6 } & $\begin{array}{l}\text { SANGAT } \\
\text { BAIK }\end{array}$ & BAIK & CUKUP & $\begin{array}{l}\text { KURANG } \\
\text { BAIK }\end{array}$ & $\begin{array}{l}\text { TIDAK } \\
\text { BAIK }\end{array}$ \\
\hline SOAL SERI A & $62,5 \%$ & $20 \%$ & $10 \%$ & $7,5 \%$ & - \\
\hline SOAL SERI B & $37,5 \%$ & $37,5 \%$ & $22,5 \%$ & - & $2,5 \%$ \\
\hline SOAL SERI C & $40 \%$ & $37,5 \%$ & $15 \%$ & $2,5 \%$ & $5 \%$ \\
\hline SOAL SERI D & $50 \%$ & $37,5 \%$ & $5 \%$ & $5 \%$ & $2,5 \%$ \\
\hline SOAL SERI E & $35 \%$ & $40 \%$ & $17,5 \%$ & $5 \%$ & $2,5 \%$ \\
\hline
\end{tabular}

\section{Pembahasan}

\section{a. Validitas}

Validitas mencerminkan sejauh mana ketepatan dan kecermatan suatu instrumen tes berfungsi sebagai alat ukur hasil belajar. Suatu tes dapat dikatakan memiliki validitas apabila tes tersebut dapat mengukur objek yang seharusnya diukur dan sesuai dengan kriteria tertentu. Butir soal dikatakan memiliki validitas yang tinggi jika skor masing-masing butir soal memiliki kesejajaran arah dengan skor totalnya. Validitas butir soal dihitung 


\section{Jurnal Pendidikan Akuntansi Indonesia, Vol. X, No. 1, Tahun 2012 Ata Nayla Amalia \& Ani Widayati \\ Halaman 1 - 26}

menggunakan rumus korelasi point biserial $\left(r_{p b i}\right)$ yang hasilnya kemudian dikonsultasikan dengan $r$ tabel pada taraf signifikansi 5\%. Jumlah siswa yang digunakan sebagai subjek penelitian di Kota Yogyakarta adalah 715 siswa dengan rincian soal seri A yang mengerjakan 139 siswa, soal seri B 145 siswa, soal seri C 150 siswa, soal seri D 145 siswa, dan soal seri E 136 siswa.

Dengan demikian nilai $\mathrm{r}$ tabel untuk masing-masing soal yaitu $r_{t}=0,165$ untuk soal seri A, $r_{t}=0,162$ untuk soal seri $\mathrm{B}, r_{t}=0,159$ untuk soal seri $\mathrm{C}, r_{t}=0,162$ untuk soal seri $\mathrm{D}$, dan $r_{t}=0,167$ untuk soal seri E. Hasil penelitian dan analisis terhadap validitas item soal Tes Kendali Mutu kelas XII SMA mata pelajaran Ekonomi Akuntansi di Kota Yogyakarta tahun 2012 berdasarkan bahwa $r_{p b i} \geq r_{t}$ berarti valid, sedangkan apabila $r_{p b i}<r_{t}$ maka soal tidak valid.

Hasil penelitian menunjukkan bahwa soal yang valid berjumlah $87,5 \%$ untuk soal seri A, $95 \%$ untuk soal seri B, $75 \%$ untuk soal seri C, $82,5 \%$ untuk soal seri D, dan $75 \%$ untuk soal seri E. Untuk soal yang tidak valid sebanyak 12,5\% untuk soal seri A, 5\% untuk soal seri B, $25 \%$ untuk soal seri C, $17,5 \%$ untuk soal seri D, dan $25 \%$ untuk soal seri E.

Hasil penelitian ini diperkuat dengan adanya teori validitas menurut Anas Sudijono (2011: 183) bahwa butir soal yang memiliki validitas yang tinggi mencerminkan soal tersebut telah memiliki kehandalan dan tidak perlu diragukan ketepatannya dalam mengukur kemampuan peserta didik. Untuk butir soal yang memiliki validitas yang rendah mencerminkan soal tersebut tidak valid sehingga perlu dilakukan tindakan terhadap soal tersebut.

Selain itu, hasil penelitian ini juga selaras dengan penelitian sebelumnya yang telah dilakukan oleh Rika Dwi Wibowo bahwa soal-soal yang digunakan dalam tes haruslah soal yang valid. Butir soal yang tidak valid dan dinyatakan sebagai soal yang gugur sebaiknya diperbaiki, sedangkan butir soal yang valid dapat digunakan kembali dan dimasukkan dalam bank soal.

Berdasarkan uraian di atas dapat disimpulkan bahwa soal Tes Kendali Mutu kelas XII SMA mata pelajaran Ekonomi Akuntansi di Kota Yogyakarta tahun 2012 termasuk soal yang baik berdasarkan validitasnya. Butir soal yang tidak valid sebaiknya diperbaiki dengan cara meningkatkan penguasaan teknis tentang penyusunan butir-butir soal. Soal dapat menjadi valid karena telah mencakup materi yang benar-benar mewakili sasaran ukurnya. Tim pembuat soal dapat meminta pendapat dari ahli untuk memantapkan validitas soal yang telah 
dibuat. Hal ini berarti bahwa validitas merupakan ciri-ciri tes yang penting sehingga tim pembuat soal dapat memberikan masukan kepada Dinas Pendidikan Kota Yogyakarta supaya seluruh soal yang digunakan adalah soal yang valid.

\section{b. Reliabilitas}

Analisis soal secara keseluruhan dapat dilihat berdasarkan indeks reliabilitas soal. Reliabilitas soal adalah tingkat atau derajat konsistensi dari suatu instrumen untuk mengukur sehingga dapat dipercaya. Reliabilitas soal dihitung dengan menggunakan rumus KR-20. Interpretasi koefisien reliabilitas adalah apabila $r_{11} \geq 0,70$ maka soal yang diujikan memiliki reliabilitas yang tinggi, tetapi apabila $r_{11}<0,70$ maka soal yang diujikan memiliki reliabilitas yang rendah atau tidak reliabel.

Hasil penelitian menunjukkan bahwa soal Tes Kendali Mutu kelas XII SMA mata pelajaran Ekonomi Akuntansi di Kota Yogyakarta tahun 2012 memiliki indeks reliabilitas sebesar 0,833 untuk soal seri A; 0,843 untuk soal seri B; 0,803 untuk soal seri C; 0,785 untuk soal seri D; dan 0,768 untuk soal seri E. Hasil tersebut menunjukkan bahwa masing-masing seri soal memiliki koefisien reliabilitas yang berbeda dengan tingkat reliabilitas yang sama yaitu memiliki reliabilitas yang tinggi.

Hasil penelitian ini didukung dengan adanya teori dari Anas Sudijono (2011: 209) bahwa apabila $r_{11} \geq 0,70$ maka soal yang diujikan memiliki reliabilitas yang tinggi, tetapi apabila $r_{11}<0,70$ maka soal yang diujikan memiliki reliabilitas yang rendah atau tidak reliabel. Penelitian ini juga selaras dengan penelitian sebelumnya yang dilakukan oleh Ika Ratna Kurniasih bahwa reliabilitas sebuah soal merupakan persyaratan pada sebuah tes sebagai alat evaluasi sehingga soal yang baik adalah soal yang memiliki reliabilitas yang tinggi.

Berdasarkan uraian di atas dapat disimpulkan bahwa soal Tes Kendali Mutu kelas XII SMA mata pelajaran Ekonomi Akuntansi di Kota Yogyakarta tahun 2012 merupakan soal yang reliabel. Soal Tes Kendali Mutu kelas XII SMA mata pelajaran Ekonomi Akuntansi di Kota Yogyakarta tahun 2012 seri A, B, C. D, dan E memiliki reliabilitas yang sama yaitu memiliki reliabilitas tinggi. 


\section{Jurnal Pendidikan Akuntansi Indonesia, Vol. X, No. 1, Tahun 2012 Ata Nayla Amalia \& Ani Widayati}

Halaman 1 - 26

\section{c. Tingkat Kesukaran}

Butir-butir item tes hasil belajar dapat dikatakan sebagai butir item yang baik apabila butir-butir tes tersebut tidak terlalu sukar dan tidak pula terlalu mudah, dengan kata lain derajat kesukaran tes tersebut adalah sedang atau cukup. Soal yang terlalu mudah tidak merangsang siswa untuk mempertinggi usaha memecahkannya. Sebaliknya soal yang terlalu sulit akan menyebabkan siswa menjadi putus asa dan tidak mempunyai semangat untuk mencoba lagi karena di luar jangkauannya. Butir soal yang baik adalah butir soal yang termasuk kategori sedang yaitu memiliki indeks kesukaran 0,300-0,699.

Berdasarkan hasil penelitian diketahui bahwa butir soal Tes Kendali Mutu kelas XII SMA mata pelajaran Ekonomi Akuntansi di Kota Yogyakarta tahun 2012 seri A yang tergolong sukar berjumlah 32,5\%, soal yang tergolong sedang berjumlah $62,5 \%$, dan soal yang tergolong mudah berjumlah $5 \%$. Soal seri B yang tergolong sukar berjumlah $25 \%$, soal yang tergolong sedang berjumlah $70 \%$, dan soal yang tergolong mudah berjumlah $5 \%$. Soal seri $\mathrm{C}$ yang tergolong sukar berjumlah $27,5 \%$, soal yang tergolong sedang berjumlah $65 \%$, dan soal yang tergolong mudah berjumlah 7,5\%. Soal seri D yang tergolong sukar berjumlah $40 \%$, soal yang tergolong sedang berjumlah 52,5\%, dan soal yang tergolong mudah berjumlah 7,5\%. Soal seri E yang tergolong sukar berjumlah $37,5 \%$, soal yang tergolong sedang berjumlah $47,5 \%$, dan soal yang tergolong mudah berjumlah $15 \%$.

Hasil penelitian ini didukung dengan adanya teori menurut Anas Sudijono (2011: 370) bahwa bermutu atau tidaknya butir item tes hasil belajar dapat diketahui dari tingkat kesukaran butir tes tersebut, maka salah satu analisis yang harus dilakukan untuk mengetahui apakah butir soal dapat dikatakan baik sebagai alat evaluasi adalah analisis terhadap tingkat kesukaran. Penelitian ini juga selaras dengan penelitian sebelumnya yang dilakukan oleh Ika Ratna Kurniasih bahwa butir soal yang baik adalah butir soal yang memiliki tingkat kesukaran sedang.

Dari uraian di atas dapat disimpulkan bahwa soal Tes Kendali Mutu kelas XII SMA mata pelajaran Ekonomi Akuntansi di Kota Yogyakarta tahun 2012 merupakan soal yang baik. Soal Tes Kendali Mutu kelas XII SMA mata pelajaran Ekonomi Akuntansi di Kota Yogyakarta tahun 2012 seri A, B, C. D, dan E memiliki tingkat kesukaran yang sama yaitu memiliki tingkat kesukaran sedang.

Untuk butir soal kategori sedang sebaiknya butir item tersebut segera dicatat dalam bank soal, selanjutnya soal tersebut dapat dikeluarkan lagi dalam tes hasil belajar pada waktu 


\section{Jurnal Pendidikan Akuntansi Indonesia, Vol. X, No. 1, Tahun 2012 Ata Nayla Amalia \& Ani Widayati}

Halaman 1 - 26

yang akan datang. Untuk butir kategori sukar dapat dilakukan tindakan yaitu butir soal tersebut dibuang dan tidak akan dikeluarkan lagi dalam tes hasil belajar yang akan datang atau diteliti ulang, dilacak, dan ditelusuri sehingga dapat diketahui faktor yang menyebabkan butir soal yang bersangkutan sulit dijawab oleh peserta didik. Untuk butir soal yang mudah tindakan yang dilakukan sama halnya dengan perlakuan pada butir soal kategori sukar.

\section{d. Daya Pembeda}

Daya pembeda item adalah kemampuan suatu butir item tes hasil belajar untuk dapat membedakan antara peserta didik yang berkemampuan tinggi (menguasai materi) dengan peserta didik yang berkemampuan rendah (kurang menguasai materi). Daya pembeda item dapat diketahui dengan melihat besar kecilnya angka indeks diskriminasi item.

Berdasarkan hasil penelitian diketahui bahwa butir soal Tes Kendali Mutu kelas XII SMA mata pelajaran Ekonomi Akuntansi di Kota Yogyakarta tahun 2012 seri A terdiri dari 7,5\% memiliki daya pembeda yang jelek, 17,5\% tergolong cukup, 55\% tergolong baik, $15 \%$ tergolong baik sekali, dan 5\% tergolong negatif. Soal seri B terdiri dari 2,5\% memiliki daya pembeda yang jelek, 22,5\% tergolong cukup, $60 \%$ tergolong baik, 12,5\% tergolong baik sekali, dan 2,5\% tergolong negatif. Soal seri $\mathrm{C}$ terdiri dari $15 \%$ memiliki daya pembeda yang jelek, 7,5\% tergolong cukup, 57,5\% tergolong baik, $10 \%$ tergolong baik sekali, dan 10\% tergolong negatif. Soal seri D terdiri dari $10 \%$ memiliki daya pembeda yang jelek, 22,5\% tergolong cukup, 55\% tergolong baik, 5\% tergolong baik sekali, dan 7,5\% tergolong negatif. Soal seri E terdiri dari 12,5\% memiliki daya pembeda yang jelek, 17,5\% tergolong cukup, $57,5 \%$ tergolong baik, $5 \%$ tergolong baik sekali, dan 7,5\% tergolong negatif.

Hasil penelitian ini diperkuat dengan adanya teori menurut Anas Sudijono (2011: 386) bahwa mengetahui daya pembeda item sangat penting, sebab salah satu dasar pegangan untuk menyusun butir tes hasil belajar adalah adanya anggapan bahwa kemampuan antara peserta didik adalah berbeda maka salah satu analisis yang harus dilakukan untuk mengetahui apakah butir soal dapat dikatakan baik sebagai alat evaluasi adalah analisis terhadap daya pembeda.

Penelitian ini juga selaras dengan penelitian sebelumnya yang dilakukan oleh Finda Lestari bahwa semakin tinggi koefisien daya pembeda maka semakin mampu soal tersebut membedakan peserta didik yang menguasai kompetensi dengan peserta didik yang kurang menguasai kompetensi. Jika peserta didik yang telah menguasai kompetensi mampu 


\section{Jurnal Pendidikan Akuntansi Indonesia, Vol. X, No. 1, Tahun 2012 Ata Nayla Amalia \& Ani Widayati}

Halaman 1 - 26

menjawab soal dengan benar sedangkan peserta didik yang kurang menguasai kompetensi menjawab soal dengan salah maka soal tersebut dapat dikatakan telah memiliki daya pembeda.

Dari uraian di atas dapat disimpulkan bahwa soal Tes Kendali Mutu kelas XII SMA mata pelajaran Ekonomi Akuntansi di Kota Yogyakarta tahun 2012 merupakan soal yang baik. Soal Tes Kendali Mutu kelas XII SMA mata pelajaran Ekonomi Akuntansi di Kota Yogyakarta tahun 2012 seri A, B, C. D, dan E memiliki daya pembeda yang sama yaitu dengan daya pembeda baik. Soal yang didominasi butir-butir soal dengan daya pembeda yang tidak berfungsi dengan baik menyebabkan peserta didik dengan kemampuan rendah dapat menjawab dengan benar sedangkan peserta didik yang berkemampuan tinggi menjawab salah. Daya pembeda soal dapat digunakan untuk meningkatkan kualitas soal berdasarkan data empirik dari analisis butir. Indeks daya beda dapat menunjukkan apakah soal tersebut baik, direvisi, atau ditolak.

\section{e. Efektivitas Pengecoh/Distractor}

Sebuah pengecoh atau distraktor dapat dikatakan berfungsi dengan baik apabila distraktor tersebut mempunyai daya tarik yang besar bagi peserta tes yang kurang memahami konsep atau kurang menguasai bahan. Suatu distraktor dapat dikatakan berfungsi dengan baik jika paling sedikit dipilih oleh $5 \%$ pengikut tes.

Hasil penelitian butir soal Tes Kendali Mutu kelas XII SMA mata pelajaran Ekonomi Akuntansi di Kota Yogyakarta tahun 2012 menunjukkan distractor soal sudah berfungsi dengan baik. Hal ini dapat dilihat melalui persentase distractor yang berkualitas sangat baik sebesar $62,5 \%$ untuk soal seri A; 37,5\% untuk soal seri B; $40 \%$ untuk soal seri C; $50 \%$ untuk soal seri D; dan 35\% untuk soal seri E. Soal dengan distractor yang baik sebesar $20 \%$ untuk soal seri A; $40 \%$ untuk soal seri B; 40\% untuk soal seri C; 37,5\% untuk soal seri D; dan 40\% untuk soal seri E. Soal dengan distractor yang cukup sebesar 10\% untuk soal seri A; $20 \%$ untuk soal seri B; $12,5 \%$ untuk soal seri C; $5 \%$ untuk soal seri D; dan 17,5\% untuk soal seri E. Soal dengan distractor yang kurang baik sebesar 7,5\% untuk soal seri A; 0\% untuk soal seri B; 2,5\% untuk soal seri C; 5\% untuk soal seri D; dan 5\% untuk soal seri E. Soal dengan distractor yang tidak baik sebesar $0 \%$ untuk soal seri A; 2,5\% untuk soal seri B; $5 \%$ untuk soal seri C; $2,5 \%$ untuk soal seri $\mathrm{D} ;$, dan 2,5\% untuk soal seri E. 
Hasil penelitian ini diperkuat dengan adanya teori menurut Daryanto (2007: 193) bahwa distraktor dapat dikatakan berfungsi dengan baik jika paling sedikit dipilih oleh 5\% pengikut tes. Penelitian ini juga selaras dengan penelitian sebelumnya yang dilakukan oleh Finda Lestari bahwa butir soal yang baik pengecohnya akan dipilih secara merata oleh peserta didik yang menjawab salah, sebaliknya butir soal yang kurang baik pengecohnya dipilih secara tidak merata.

Besarnya persentase butir soal dengan kualitas distractor yang kurang baik mengidentifikasi bahwa pengecoh belum dapat berfungsi dengan baik, pengecoh terlalu mencolok, menyesatkan, dan cenderung heterogen. Pengecoh tersebut tidak memiliki daya tarik yang besar bagi peserta tes yang kurang memahami konsep atau kurang menguasai materi mata pelajaran Ekonomi Akuntansi

\section{Penutup}

\section{Kesimpulan}

Berdasarkan hasil penelitian dan pembahasan butir soal Tes Kendali Mutu kelas XII SMA mata pelajaran Ekonomi Akuntansi di Kota Yogyakarta tahun 2012 maka dapat disimpulkan bahwa secara keseluruhan soal Tes Kendali Mutu kelas XII SMA mata pelajaran Ekonomi Akuntansi di Kota Yogyakarta tahun 2012 baik seri A, B, C, D, maupun E termasuk soal dengan kualitas baik.

\section{Saran}

Berdasarkan hasil analisis butir soal secara keseluruhan yang terdiri validitas, reliabilitas, tingkat kesukaran, daya pembeda, dan efektivitas pengecoh soal Tes Kendali Mutu kelas XII SMA mata pelajaran Ekonomi Akuntansi di Kota Yogyakarta tahun 2012 maka saran yang dapat diajukan sebagai berikut:

a. Bagi Kepala Dinas Pendidikan Kota Yogyakarta

Hasil penelitian ini, dapat dijadikan bahan pertimbangan dalam menentukan berbagai kebijakan dalam meningkatkan kualitas soal Tes Kendali Mutu kelas XII SMA mata pelajaran Ekonomi Akuntansi di Kota Yogyakarta dan mengkaji ulang kembali soal-soal tahun 2012 yang kurang baik dan tidak baik jika akan digunakan kembali pada tahun berikutnya. Meskipun soal Tes Kendali Mutu hanya sebagai pengukur terhadap kemampuan siswa sebelum melaksanakan ujian nasional, akan tetapi soal Tes Kendali Mutu tetap harus memiliki kualitas yang baik sebab tes ini tidak hanya sebagai seleksi tetapi tes juga mampu 
memberikan informasi atau saran terhadap pengguna tes untuk melakukan langkah apa ke depan yang harus dilakukan. Soal-soal yang baik harus tetap dipertahankan kualitasnya dan dapat dimasukkan dalam bank soal sedangkan soal yang kurang baik dan tidak baik sebaiknya direvisi sesuai dengan indikator penyebab kegagalan sehingga dapat menjadi soal yang baik. Untuk periode Tes Kendali Mutu mata pelajaran Ekonomi Akuntansi selanjutnya perlu disusun instrument soal yang berkualitas dengan memperhatikan validitas, reliabilitas, tingkat kesukaran, daya pembeda, dan efektivitas pengecoh/distractor.

b. Bagi Tim Pembuat Soal/Musyawarah Guru Mata Pelajaran (MGMP)

Kegiatan analisis butir soal hendaknya dilakukan secara berkelanjutan sehingga dapat mengetahui kualitas butir-butir soal yang digunakan dalam melakukan penilaian hasil belajar. Tim pembuat soal sebaiknya juga mengembangkan kemampuannya dalam penyusunan soal serta analisis butir soal sehingga dapat menyusun soal dengan baik dan dapat melakukan analisis butir soal. Dengan demikian soal yang disusun memiliki kualitas yang baik. Selain itu dengan mengikuti kegiatan pelatihan tersebut tim pembuat soal (dalam hal ini guru) tidak hanya memiliki kemampuan dalam mengajar peserta didik saja, tetapi juga memiliki kemampuan dalam menyusun soal dan menganalisis butir soal dengan baik.

\section{E. Daftar Pustaka}

Anas Sudijono. (2011). Pengantar Evaluasi Pendidikan. Jakarta : PT Rajagrafindo Persada.

Asmi, dkk. (2011). Ranah Pengetahuan Menurut Bloom. Diambil dari: http://rian.hilman.web.id/wp-content/uploads/2011/01/RANAH-PENGETAHUAN-

MENURUT-BLOOM.doc, diakses pada tanggal 12 Februari 2012

Chabib Thoha. (2003). Teknik Evaluasi Pendidikan. Jakarta: Rajawali Pers.

Daryanto. (2007). Evaluasi Pendidikan. Jakarta: PT Rineka Cipta.

Depdiknas. (2003). Standar Kompetensi Mata Pelajaran Ekonomi SMA \& MA. Jakarta: Balitbang Depdiknas.

Balitbang Depdiknas.

DIKPORA. (2011). Peraturan Mendiknas. Diambil dari: http://www.pendidikandiy.go.id/?view=baca_isi_lengkap\&id_p=12, diakses tanggal 9 Januari 2012.

Finda Lestari. (2007). Analisis Butir Soal Ujian Ekonomi Akuntansi Kelas XI dan XII IS Semester Gasal SMA Negeri Cirebon Tahun Ajaran 2006/2007. Skripsi. Yogyakarta: UNY. 
Ika Ratna Kurniasih. (2009). Analisis Butir Tes Sumatif Buatan Guru Ekonomi Akuntansi Kelas XI IPS di SMA Negeri 1 Sewon Tahun Ajaran 2008/2009. Skripsi. Yogyakarta: UNY.

Iskandar Putong. (2002). Pengantar Ekonomi Mikro dan Makro. Jakarta: Ghalia Indonesia.

Karjono Natar. (2007). Panduan Analisis Butir Soal. Diambil dari: http://www.ut.ac.id/suplemen/pama3212/panduan analisis_butir_soal.doc. diakses pada tanggal 12 Februari 2012.

Kieso, Donald E., Weygandt, Jerry. J., \& Kimmel, Paul D. (2007). Accounting Principles Pengantar Akutans. Jakarta: Penerbit Salemba Empat.

Nana Sudjana. (2006). Penilaian Hasil Belajar Proses Belajar Mengajar: Bandung: PT. Remaja Rosdakarya.

Rika Dwi Wibowo. (2009). Analisis Butir Soal Ulangan Umum Ekonomi Kelas XI IPS Semester Ganjil SMAN 1 Pakem, Sleman, Yogyakarta Tahun Ajaran 2008/2009. Skripsi. Yogyakarta: UNY.

Samuelson. ( 2003). Ilmu Makro Ekonomi. Jakarta: PT Media Global Edukasi.

Sugiyono, (2010). Metodologi Penelitian Bisnis. Bandung: Alfabeta. (2007). Statistik untuk Penelitian. Bandung: Alfabeta.

Suharsimi Arikunto. (2009). Dasar-Dasar Evaluasi Pendidikan. Jakarta: Bumi Aksara Sumarsono. (2004). Akuntansi Suatu Pengantar. Jakarta: Penerbit Salemba Empat Suwardjono. (2010). Teori Akuntansi Perekayasaan Pelaporan Keuangan. Yogyakarta: BPFE.

Sukardi, (2011). Metodologi Penelitian Pendidikan. Jakarta: Bumi Aksara.

Undang-Undang Republik Indonesia. (2003). Undang-Undang Republik Indonesia, Nomor 20, Tahun 2003, tentang Pendidikan.

Yulian, dkk. (2003). Akuntansi. Jakarta. Bumi Aksara.

Zainal Arifin. (2011). Evaluasi Pembelajaran. Bandung : PT Remaja Rosdakarya. 